\title{
The Effect of Very-Low-Calorie Diet on Mitochondrial Dysfunction in Subcutaneous Adipose Tissue and Peripheral Monocytes of Obese Subjects with Type 2 Diabetes Mellitus
}

\author{
M. URBANOVÁ ${ }^{1}$, M. MRÁZ ${ }^{2,3}$, V. ĎUROVCOVÁ, P. TRACHTA ${ }^{4}$, J. KLOUČKOVÁ ${ }^{2,5}$, \\ P. KAVÁLKOVÁ ${ }^{2}$, D. HALUZÍKOVÁ ${ }^{6}$, Z. LACINOVÁ ${ }^{2,5}$, H. HANSÍKOVÁ \\ L. WENCHICH ${ }^{1,7}$, M. KRŠEK ${ }^{4,8}$, M. HALUZÍK ${ }^{2,5}$
}

${ }^{1}$ Institute of Rheumatology, Prague, Czech Republic, ${ }^{2}$ Institute of Medical Biochemistry and Laboratory Diagnostics, First Faculty of Medicine, Charles University in Prague and General University Hospital, Prague, Czech Republic, ${ }^{3}$ Diabetes Centre, Institute for Clinical and Experimental Medicine, Prague, Czech Republic, ${ }^{4}$ Third Department of Medicine - Department of Endocrinology and Metabolism; First Faculty of Medicine, Charles University in Prague and General University Hospital, Prague, Czech Republic, ${ }^{5}$ Centre for Experimental Medicine, Institute for Clinical and Experimental Medicine, Prague, Czech Republic, ${ }^{6}$ Department of Sports Medicine, First Faculty of Medicine, Charles University in Prague and General University Hospital, Prague, Czech Republic, ${ }^{7}$ Laboratory for the Study of Mitochondrial Disorders, Department of Pediatrics and Adolescent Medicine, First Faculty of Medicine, Charles University in Prague and General University Hospital, Prague, Czech Republic, ${ }^{8}$ Second Department of Medicine, Third Faculty of Medicine, Charles University and University Hospital Královské Vinohrady, Prague, Czech Republic

Received August 18, 2016

Accepted April 7, 2017

On-line July 18, 2017

\section{Summary}

Mitochondrial dysfunction is a potentially important player in the development of insulin resistance and type 2 diabetes mellitus (T2DM). We investigated the changes of mRNA expression of genes encoding main enzymatic complexes of mitochondrial respiratory chain in subcutaneous adipose tissue (SCAT) and peripheral monocytes (PM) of 11 subjects with simple obesity (OB), 16 obese patients with T2DM and 17 healthy lean subjects $(C)$ before and after very low-calorie diet (VLCD) using quantitative real time PCR. At baseline in SCAT, both T2DM and $O B$ group had decreased mRNA expression of all investigated mitochondrial genes with the exception of 2 complex I (NDUFA 12) and complex IV (COX 4/1) enzymes in OB subjects. In contrast, in PM only the expression of complex I enzymes NDUFA 12 and MT-ND5 was reduced in both T2DM and $\mathrm{OB}$ subjects along with decreased expression of citrate synthase (CS) in T2DM group. Additionally, T2DM subjects showed reduced activity of pyruvate dehydrogenase and complex IV in peripheral blood elements. VLCD further decreased mRNA expression of CS and complex I (NT-ND5) and II (SDHA) enzymes in SCAT and complex IV (COX4/1) and ATP synthase in PM of T2DM group, while increasing the activity of complex IV in their peripheral blood elements. We conclude that impaired mitochondrial biogenesis and decreased activity of respiratory chain enzymatic complexes was present in SCAT and PM of obese and diabetic patients. VLCD improved metabolic parameters and ameliorated mitochondrial oxidative function in peripheral blood elements of T2DM subjects but had only minor and inconsistent effect on mitochondrial gene mRNA expression in SCAT and PM.

\section{Key words}

Mitochondrial dysfunction • Obesity • Type 2 diabetes mellitus • Very low-calorie diet $\bullet$ Peripheral monocytes

\section{Corresponding author}

M. Haluzik, Centre for Experimental Medicine, Institute for Clinical and Experimental Medicine, Vídeňská 1958/9, 14021 Prague 4, Czech Republic. E-mail: halm@medicon.cz 


\section{Introduction}

Obesity and type 2 diabetes mellitus (T2DM), frequently interconnected within the metabolic syndrome, are among the leading causes of morbidity worldwide (Alberti and Zimmet 2013). Currently, the number of diabetic patients has reached pandemic levels; approximately 382 million people worldwide, or $8.3 \%$ of adults, suffer from diabetes, out of which $80-95 \%$ account for T2DM (IDF, $6{ }^{\text {th }}$ Diabetes Atlas, 2013). Type 2 diabetes is a well-known risk factor for atherosclerosis and subsequent cardiovascular and cerebrovascular diseases as well as for specific types of cancer (Paneni et al. 2014, Laakso and Kuusisto 2014, Vigneri et al. 2009, Matloch et al. 2016).

The main pathophysiological features of T2DM are insulin resistance and hyperglycemia (Stumvoll and Gerich 2001). Despite extensive research, the exact cause of insulin resistance is still not known, although a number of mechanisms are being considered (Wajchenberg 2000, Indulekha et al. 2011, Rasouli and Kern 2008). Particularly, endocrine dysfunction of adipose tissue, mainly the visceral adipose tissue (VAT), and chronic subclinical inflammation are the primary suspects contributing to decreased insulin sensitivity and impaired insulin production in pancreatic $\beta$-cells (Scrapellini 2012). Moreover, recent studies have revealed a possible connection between pancreatic $\beta$-cell dysfunction, insulin resistance and defects in mitochondrial metabolic processes (Sivitz and Yorek 2010).

Mitochondria are evolutionarily ancient organelles located in the cytosol of eukaryotic cells. Described as "cellular power plants", they play a central role in cell metabolism by generating energy in the form of ATP (adenosine-tri-phosphate) from substrates such as saccharides and fatty acids in the process of oxidative phosphorylation (Duchen 2004). The oxidative capacity of mitochondria is determined by the expression levels of enzymatic complexes involved in oxidative phosphorylation, although the size and number of mitochondria are also of importance (Ritz and Berrut 2005). In simple obesity, the expression of genes encoding components of mitochondrial oxidative phosphorylation as well as mitochondrial oxidative phosphorylation capacity in white adipose tissue were found to be reduced along with an inverse correlation of this capacity with BMI (Mustelin et al. 2008, Fischer et al. 2015). In females, obesity and insulin resistance were also associated with decreased expression of mitochondrial complex I, III and IV components in both subcutaneous and visceral adipose tissue (Soronen et al. 2012). Furthermore, subjects with T2DM were shown to have reduced amount and smaller-sized mitochondria as well as impaired mitochondrial oxidative activity due to decreased expression of the mitochondrial respiratory chain enzymes in skeletal muscle and pancreatic $\beta$-cells, resulting in the development of insulin resistance and $\beta$-cell dysfunction (Morino et al. 2005, Kelley et al. 2002, Petersen et al. 2004, Kraunsoe et al. 2010, Mootha et al. 2003). However, little is known about mitochondrial function in white adipose tissue of obese diabetic patients. Moreover, very limited data currently exist regarding the mitochondria in peripheral monocytes, which are considered one of the main contributors to the development of local as well as systemic low-grade inflammation associated with obesity and insulin resistance (Hotamisligil 2006, Suganami et al. 2005, Del Pozo et al. 2011). To this end, we assessed the mRNA gene expression and enzymatic activity of components of the mitochondrial respiratory chain in subcutaneous adipose tissue (SCAT) and peripheral monocytes (PM) of subjects with T2DM and obesity. Furthermore we hypothesized that the improvement of metabolic parameters after short-term diet intervention could be in part mediated by changes in mitochondrial oxidative function and gene expression in SCAT and PM.

\section{Material and Methods}

\section{Study subjects}

Eleven subjects with simple obesity (9 females, 2 males - OB group), 16 obese patients with type 2 diabetes mellitus (13 females, 3 males - T2DM group) and 17 healthy lean age-matched control subjects (12 females, 5 males - C group) were included in the study. Six subjects in T2DM group were treated with oral antidiabetic drugs (OAD), 5 were using a combination of $\mathrm{OAD}$ and insulin and 5 were on diet only. Fourteen out of the 16 subjects received antihypertensive treatment, 5 were on lipid-lowering therapy ( 4 on a statin, 1 on a combination of statin and fibrate) and 3 had thyroid hormone replacement therapy. In OB group, 5 subjects were treated with antihypertensives, 2 with a statin and 3 with thyroid hormone replacement agents. All treatment remained unchanged for at least three months prior to the start of the study. Control subjects had no history of obesity and/or diabetes mellitus, arterial hypertension, or lipid metabolism disturbances and received no 
medication. Blood tests confirmed normal blood count, biochemical and hormonal parameters. None of the study subjects had active malignancy or acute infectious disease. The body weight of all study participants remained stable for at least three months before enrollment into the study.

All subjects in T2DM group underwent a routinely used 3-week very low-calorie diet (VLCD) with energy intake of 2,500 kJ per day (600 kcal per day) (Grams and Garvey 2015) at the Third Department of Medicine, General University Hospital in Prague. The diet was composed of $55 \mathrm{~g}$ of proteins, $50 \mathrm{~g}$ of saccharides and $20 \mathrm{~g}$ of fats divided into three main meals and was supervised by a dietitian nurse.

Written informed consent was signed by all participants before the beginning of the study. The study was approved by Human Ethics Review Board, First Faculty of Medicine and General University Hospital, Prague, Czech Republic and was performed in accordance with the guidelines proposed in Declaration of Helsinki.

Anthropometric examination, blood and adipose tissue sampling

All patients with T2DM were examined twice; at baseline before the beginning of any intervention and after 3 weeks of VLCD, while obese and normal-weight healthy subjects were examined only once. All subjects were measured and weighed, and their body mass index (BMI) was calculated. Blood samples for biochemical and hormonal measurements were withdrawn between $07.00 \mathrm{~h}$ and $08.00 \mathrm{~h}$ after $12 \mathrm{~h}$ of overnight fasting. Blood samples were separated by centrifugation for $10 \mathrm{~min}$ at $1000 \mathrm{x}$ g within $30 \mathrm{~min}$ from blood collection. Serum was subsequently stored in aliquots at $-80{ }^{\circ} \mathrm{C}$ until further analysis. Blood samples for monocyte isolation were collected in Na-EDTA anticoagulant from all subjects and processed within 1-2 h. Samples of subcutaneous adipose tissue for mRNA expression analysis were obtained from abdominal region using subcutaneous needle aspiration biopsy. Approximately $100 \mathrm{mg}$ of adipose tissue was collected to $1 \mathrm{ml}$ of RNA stabilization reagent (RNAlater, Qiagen, Hilden, Germany) and stored at $-80^{\circ} \mathrm{C}$ until further analysis.

\section{Hormonal and biochemical assays}

Serum insulin concentrations were measured by commercial RIA kit (Cis Bio International, Gif-sur-Yvette, France). Biochemical parameters (glucose, total and HDL-cholesterol, triglycerides) were measured at the Department of Biochemistry of General University Hospital in Prague by standard laboratory methods. The value of LDL-cholesterol was calculated according to Friedewald formula (Friedewald et al. 1972). The homeostasis model assessment (HOMA) was calculated as HOMA-IR index using the following formula: fasting serum insulin (mIU/l) $x$ fasting serum glucose $(\mathrm{mmol} / \mathrm{l}) / 22.5$. Glycated hemoglobin was analyzed by high performance liquid chromatography (HPLC) on Variant II BioRad analyzer (BioRad).

\section{$P M$ separation and total RNA isolation from monocytes and adipose tissue}

Peripheral blood leukocytes were obtained from blood samples using Ficoll-Paque ${ }^{\mathrm{TM}}$ Plus (Amersham Biosciences AB, Sweden). For each blood sample, $3.5 \mathrm{ml}$ of Ficoll-Paque ${ }^{\mathrm{TM}}$ Plus was placed in a Falcon tube, and then $5 \mathrm{ml}$ of blood sample was slowly added. Immediately after this preparation, tubes were centrifuged. After centrifugation, leukocyte agglomerates were placed in a tube containing $10 \mathrm{ml}$ of PBS $(0.01 \mathrm{M}$ PBS), pH 7.4. Tubes were centrifuged again, the supernatant was discarded, and the cell pellet was dissolved in PBS. After centrifugation the supernatant was discarded and the pellet was dissolved in DE-GAS buffer $(0.01 \mathrm{M}$ PBS with $0.5 \mathrm{M}$ EDTA, $\mathrm{pH} 8$ and $1 \%$ BSA). Monocytes were isolated from the cell pellet with magnetic activated cell sorting technique (MiniMacs Miltenyi Biotec, Bergisch Gladbach, Germany) using microbeads coated with CD14 antibody (MACS CD14 MicroBeads; Miltenyi Biotec). Total RNA was extracted from $\mathrm{CD} 14+$ monocyte samples on MagNA Pure instrument using MagNA Pure Compact RNA Isolation kit (Roche Diagnostics GmbH, Germany). Samples of SCAT were homogenized on a MagNA Lyser Instrument using MagNA Lyser Green Beads (Roche Diagnostics $\mathrm{GmbH}$ ). Total RNA was extracted from the homogenized sample using RNeasy Lipid Tissue Mini Kit (Qiagen $\mathrm{GmbH}$, Hilden, Germany), and cDNA was prepared as described in detail previously (Dolezalova et al. 2007).

\section{Mitochondrial enzyme activity assay}

Platelets were isolated from $9 \mathrm{ml}$ of blood with citrate by differential centrifugation according to Fox et al. (1992) without addition of prostacyclin. Platelet protein was determined by the method of Lowry et al. (1951). The activities of respiratory chain complexes NADH-coenzyme $\mathrm{Q}_{10}$ reductase (NQR, complex I), 
succinate-coenzyme $\mathrm{Q}_{10}$ reductase ( $\mathrm{SQR}$, complex II), cytochrome $c$ oxidase (COX, complex IV), NADH-cytochrome $c$ reductase (NCCR, complex $\mathrm{I}+\mathrm{III}$ ) and the activity of citrate synthase (CS) serving as control enzyme were measured spectrophotometrically (Bohm et al. 2003, Srere 1969). All spectrophotometric measurements were performed in $1 \mathrm{ml}$ cuvettes $(1 \mathrm{~cm}$, $37^{\circ} \mathrm{C}$ ) using double beam spectrophotometer Shimadzu UV-160. $100 \mu \mathrm{g}$ of platelet protein was used for each enzyme assay. Each value represents the mean of 2 measurements on each platelet sample. The ratio between activity of individual respiratory chain complexes and CS was calculated to eliminate a possible effect of changes in the number of mitochondria in patient cells (Gellerich et al. 2002). Lymphocytes were isolated from EDTA-treated peripheral blood on a Ficoll medium using lymphopack tubes (Sigma) by centrifugation for $15 \mathrm{~min}$ at $800 \mathrm{xg}$. Isolated lymphocytes were resuspended in phosphorus buffer saline, rapidly frozen and stored in $-80^{\circ} \mathrm{C}$ before the measurements. The activity of the pyruvate dehydrogenase complex (PDH) was estimated as the production of ${ }^{14} \mathrm{CO}_{2}$ generated by decarboxylation of [1- $\left.{ }^{14} \mathrm{C}\right]$-pyruvate (Constantin-Teodosiu et al. 1991). All investigated genes and enzymes are summarized in Table 1.

Table 1. Enzymes of the oxidative phosphorylation and their corresponding genes.

\begin{tabular}{|c|c|c|c|c|}
\hline Enzyme complex & Abbreviation & mRNA expression & Abbreviation & $\begin{array}{c}\text { DNA } \\
\text { location }\end{array}$ \\
\hline $\begin{array}{l}\text { Pyruvate dehydrogenase } \\
\text { complex }\end{array}$ & $\mathrm{PDH}$ & Dihydrolipoate-S-acetyltransferase & $D L A T$ & nDNA \\
\hline Citrate synthase & $\mathrm{CS}$ & Citrate synthase & $C S$ & nDNA \\
\hline \multirow{2}{*}{$\begin{array}{l}N A D H-\text { coenzyme } Q_{10} \\
\text { reductase (complex I) }\end{array}$} & \multirow{2}{*}{ NQR } & $\begin{array}{c}\text { NADH - ubiquinone dehydrogenase } 1 \\
\text { alpha subcomplex } 12\end{array}$ & NDUFA 12 & nDNA \\
\hline & & $\begin{array}{c}\text { Mitochondrially encoded NADH } \\
\text { dehydrogenase } 5\end{array}$ & $M T-N D 5$ & mtDNA \\
\hline $\begin{array}{l}\text { Succinate - coenzyme } Q_{10} \\
\text { reductase (complex II) }\end{array}$ & SQR & Succinate dehydrogenase subunit A & $S D H A$ & nDNA \\
\hline $\begin{array}{l}N A D H-\text { cytochrome } c \\
\text { reductase (complex I-III) }\end{array}$ & NCCR & Cytochrome c 1 & CYC 1 & nDNA \\
\hline \multirow[t]{2}{*}{$\begin{array}{l}\text { Cytochrome c oxidase } \\
\text { (complex } I V)\end{array}$} & $\mathrm{COX}$ & $\begin{array}{c}\text { Cytochrome c oxidase subunit IV } \\
\text { isoform } 1\end{array}$ & $\operatorname{COX} 4 / 1$ & nDNA \\
\hline & & ATP synthase & ATP 50 & mtDNA \\
\hline
\end{tabular}

nDNA - nuclear DNA, mtDNA - mitochondrial DNA.

\section{Quantitative real-time PCR}

mRNA expression of selected genes was determined as described in detail elsewhere (Dolezalova et al. 2007).

\section{Statistical analysis}

Statistical analysis was performed on SigmaStat software (Systat Inc., Chicago, IL). Anthropometric, biochemical, and hormonal results are expressed as means \pm SEM. Differences in gene expression and serum parameters between study groups were evaluated using one-way ANOVA, or ANOVA on Ranks, as appropriate. Differences between T2DM subjects before and after VLCD were evaluated using paired $t$-test or Wilcoxon Signed-Rank test as appropriate. Statistical significance was assigned to $\mathrm{P}<0.05$. The Benjamini-Hochberg correction for false discovery rate was used for multiple testing of mRNA gene expression profiles in both PM and SCAT (Benjamini and Hochberg 1995). 


\section{Results}

\section{Biochemical, anthropometric and hormonal characteristics of study subjects}

Baseline

Anthropometric, biochemical and hormonal characteristics of all study groups are summarized in Table 1. As expected, both OB and T2DM groups had significantly higher body weight, BMI and waist circumference as well as elevated fasting insulin, HOMA index and triglyceride levels relative to control group, with BMI and waist circumference being even more increased in T2DM compared with non-diabetic OB subjects. T2DM patients had also markedly elevated fasting glucose and glycated hemoglobin relative to both control and OB groups. There was no significant difference in total and LDL-cholesterol in obese non- diabetic or T2DM patients compared with healthy lean controls, while HDL cholesterol was lower in T2DM than in control subjects.

\section{Influence of $V L C D$}

After 3 weeks of very low-calorie diet (VLCD) there was an overall improvement in anthropometric and biochemical parameters in the T2DM group with decreased body weight, BMI and waist circumference and a reduction in serum fasting glucose and HOMA-IR. Total and LDL cholesterol were also markedly decreased relative to baseline levels, while no significant change in HDL cholesterol and triglycerides could be seen after dietary intervention. Glycated hemoglobin was not assessed after VLCD due to its relatively short duration (Table 2).

Table 2. Clinical, hormonal, and metabolic characteristics of study subjects at baseline and after 3 weeks of VLCD.

\begin{tabular}{|c|c|c|c|c|c|}
\hline & \multirow[b]{2}{*}{$\begin{array}{c}\text { C group } \\
\mathrm{n}=17\end{array}$} & \multirow[b]{2}{*}{$\begin{array}{c}\text { OB group } \\
n=12\end{array}$} & \multicolumn{2}{|c|}{ T2DM group } & \multirow[b]{2}{*}{ P-value } \\
\hline & & & $\begin{array}{c}\text { Before VLCD } \\
\mathrm{n}=16\end{array}$ & $\begin{array}{c}\text { After VLCD } \\
n=16\end{array}$ & \\
\hline Age (years) & $46.1 \pm 2.1$ & $48.9 \pm 3.8$ & $51.6 \pm 2.5$ & $51.6 \pm 2.5$ & 0.342 \\
\hline Sex (females/males) & $12 / 5$ & $9 / 2$ & $13 / 3$ & $13 / 3$ & \\
\hline Body weight (kg) & $67.7 \pm 1.7$ & $118.6 \pm 5.6 *$ & $141.6 \pm 5.9 *$ & $129.9 \pm 5.3^{*}$ & $<\mathbf{0 . 0 0 1}$ \\
\hline$B M I\left(k g / m^{2}\right)$ & $22.8 \pm 0.5$ & $40.2 \pm 1.4 *$ & $51.5 \pm 2.0 * \circ$ & $47.3 \pm 1.9 *^{\bullet}$ & $<0.001$ \\
\hline Waist circumference (cm) & $80 \pm 2$ & $122 \pm 2 *$ & $140 \pm 4 * \circ$ & $135 \pm 4 * 0^{\bullet}$ & $<\mathbf{0 . 0 0 1}$ \\
\hline Serum fasting glucose ( $\mathrm{mmol} / \mathrm{l})$ & $4.74 \pm 0.11$ & $4.65 \pm 0.15$ & $7.86 \pm 0.95 * \circ$ & $5.94 \pm 0.51^{\bullet}$ & $<0.001$ \\
\hline$H b A 1 c(\%$ IFCC) & $3.44 \pm 0.09$ & $3.84 \pm 0.14$ & $6.03 \pm 0.52^{\circ} *$ & Not assessed & $<0.001$ \\
\hline Serum fasting insulin (mIU/l) & $6.8 \pm 0.8$ & $29.1 \pm 4.0 *$ & $34.2 \pm 3.4^{*}$ & $26.8 \pm 3.7 *$ & $<0.001$ \\
\hline$H O M A-I R$ & $1.45 \pm 0.20$ & $6.16 \pm 6.16 *$ & $12.19 \pm 1.69 *$ & $6.25 \pm 0.91 *^{\bullet}$ & $<0.001$ \\
\hline Total-cholesterol (mmol/l) & $4.79 \pm 0.23$ & $5.43 \pm 0.42$ & $4.67 \pm 0.20$ & $3.98 \pm 0.20^{\circ} * \bullet$ & 0.006 \\
\hline HDL-cholesterol (mmol/l) & $1.60 \pm 0.11$ & $1.25 \pm 0.12$ & $1.02 \pm 0.04 *$ & $1.09 \pm 0.19 *$ & $<0.001$ \\
\hline LDL-cholesterol ( $\mathrm{mmol} / \mathrm{l})$ & $2.71 \pm 0.20$ & $3.17 \pm 0.32$ & $2.84 \pm 0.18$ & $2.19 \pm 0.20^{\circ}$ & 0.037 \\
\hline Triglycerides (mmol/l) & $1.07 \pm 0.12$ & $1.98 \pm 0.31 *$ & $1.81 \pm 0.15 *$ & $1.55 \pm 0.14$ & $<0.001$ \\
\hline
\end{tabular}

Values are mean \pm SEM. Statistical significance is from one-way ANOVA or ANOVA on Ranks. Differences between T2DM subjects before and after VLCD were evaluated using paired t-test or Wilcoxon Signed-Rank test as appropriate. $* \mathrm{P}<0.05$ vs. control subjects, ${ }^{\circ} \mathrm{P}<0.05$ vs. obese non-diabetic, $\cdot \mathrm{P}<0.05$ vs. T2DM group before VLCD.

mRNA expression of respiratory chain enzyme complexes in SCAT and PM of $\mathrm{OB}$ and T2DM subjects Baseline

mRNA expression of selected respiratory chain enzymes in SCAT and PM of OB and T2DM groups is summarized in Table 2. In SCAT of T2DM subjects mRNA expression of all studied enzymes was markedly decreased at baseline relative to control group. Similarly,
OB subjects had significantly reduced mRNA expression of almost all enzymes compared with lean healthy controls except of cytochrome $\mathrm{c}$ oxidase subunit IV isoform 1 (COX 4/1) and NADH dehydrogenase 1 alpha subcomplex 12 (NDUFA 12), where the tendency to lower values did not reach statistical significance. In contrast, no major difference between diabetic and non-diabetic obese patients could be seen at baseline (data not shown). 
Peripheral monocytes showed significantly decreased mRNA expression of mitochondrially encoded NADH dehydrogenase 5 (MT-ND 5) and NDUFA 12 in both T2DM and OB groups relative to control subjects, while the expression of CS was reduced only in obese diabetic patients (Table 3). Other than that, no differences in mRNA expression in any of the studied genes could be seen between T2DM or OB group and healthy control subjects (Table 3), as well as in direct comparison between T2DM and OB group (data not shown).

Table 3. mRNA expression changes in PM and SCAT of OB and T2DM patients relative to control group at baseline.

\begin{tabular}{|c|c|c|c|c|c|c|c|c|c|}
\hline \multirow{3}{*}{$\begin{array}{l}\text { Gene } \\
\text { symbols }\end{array}$} & \multirow{3}{*}{ Gene name } & \multicolumn{4}{|c|}{ Peripheral monocytes } & \multicolumn{4}{|c|}{ Subcutaneous adipose tissue } \\
\hline & & \multicolumn{2}{|c|}{ OB } & \multicolumn{2}{|c|}{ T2DM } & \multicolumn{2}{|c|}{ OB } & \multicolumn{2}{|c|}{ T2DM } \\
\hline & & $\begin{array}{c}\text { Fold } \\
\text { change }\end{array}$ & P-value & $\begin{array}{c}\text { Fold } \\
\text { change }\end{array}$ & P-value & $\begin{array}{c}\text { Fold } \\
\text { change }\end{array}$ & P-value & $\begin{array}{c}\text { Fold } \\
\text { change }\end{array}$ & P-value \\
\hline ATP 50 & ATP synthase & 0.86 & NS & 0.99 & NS & 0.70 & $<0.001$ & 0.69 & $<0.001$ \\
\hline $\operatorname{COX} 4 / 1$ & $\begin{array}{l}\text { Cytochrome c oxidase } \\
\text { subunit IV isoform } 1\end{array}$ & 1.14 & NS & 1.04 & NS & 0.93 & NS & 0.68 & 0.001 \\
\hline CS & Citrate synthase & 0.95 & NS & 0.78 & 0.012 & 0.39 & $<0.001$ & 0.43 & $<0.001$ \\
\hline CYC 1 & Cytochrome c-1 & 0.75 & NS & 0.84 & NS & 0.54 & $<0.001$ & 0.58 & $<0.001$ \\
\hline DLAT & $\begin{array}{l}\text { Dihydrolipoate-S- } \\
\text { acetyltransferase }\end{array}$ & 0.88 & NS & 1.02 & NS & 0.39 & $<0.001$ & 0.42 & $<0.001$ \\
\hline MT-ND 5 & $\begin{array}{l}\text { Mitochondrially } \\
\text { encoded NADH } \\
\text { dehydrogenase } 5\end{array}$ & 0.55 & 0.006 & 0.64 & 0.021 & 0.54 & $<0.001$ & 0.46 & $<0.001$ \\
\hline NDUFA 12 & $\begin{array}{l}\text { NADH dehydrogenase } \\
\text { (ubiquinone) } 1 \text { alpha } \\
\text { subcomplex, } 12\end{array}$ & 0.68 & 0.006 & 0.60 & 0.002 & 0.73 & NS & 0.63 & 0.009 \\
\hline SDHA & $\begin{array}{c}\text { Succinate } \\
\text { dehydrogenase complex, } \\
\text { subunit } \mathrm{A}\end{array}$ & 0.92 & NS & 0.91 & NS & 0.70 & 0.017 & 0.51 & $<0.001$ \\
\hline
\end{tabular}

NS, nonsignificant. The mean value of the relative gene expression of control group was taken as 1.0 . $\mathrm{P} \leq 0.05$ denotes statistical significance.

\section{T2DM subjects: influence of VLCD}

There was a significant decrease in mRNA expression of CS, MTND 5, dihydrolipoate-Sacetyltransferase (DLAT) and succinate dehydrogenase subunit A (SDHA) in SCAT of T2DM patients after VLCD while the expression of other genes remained unchanged (Fig. 1). In contrast, only the expression of ATP synthase and COX 4/1 were reduced after VLCD in peripheral monocytes, whereas other studied genes showed no difference relative to baseline (Fig. 2).

\section{Activity of mitochondrial enzymatic complexes in T2DM subjects}

Baseline

In addition to mRNA expression, in T2DM subjects we also measured the activity of key enzymes and enzymatic complexes involved in the mitochondrial respiratory chain in peripheral blood elements. At baseline, the activity of the PDH complex and complex IV represented by cytochrome c oxidase (COX) was markedly decreased in T2DM relative to control group, whereas the activity of other enzymes did not show any difference between both cohorts. Interestingly, in contrast to all other analyzed enzymatic complexes T2DM patients had at baseline a non-significant increase in the activity of NADH-coenzyme $\mathrm{Q}_{10}$ reductase (NQR).

\section{Influence of $V L C D$}

Activity of NQR that was, albeit nonsignificantly, increased at baseline showed marked decrease after 3 weeks of VLCD. Other than that, VLCD only increased the activity of COX, while having no effect on other respiratory chain enzymes (Fig. 3). 


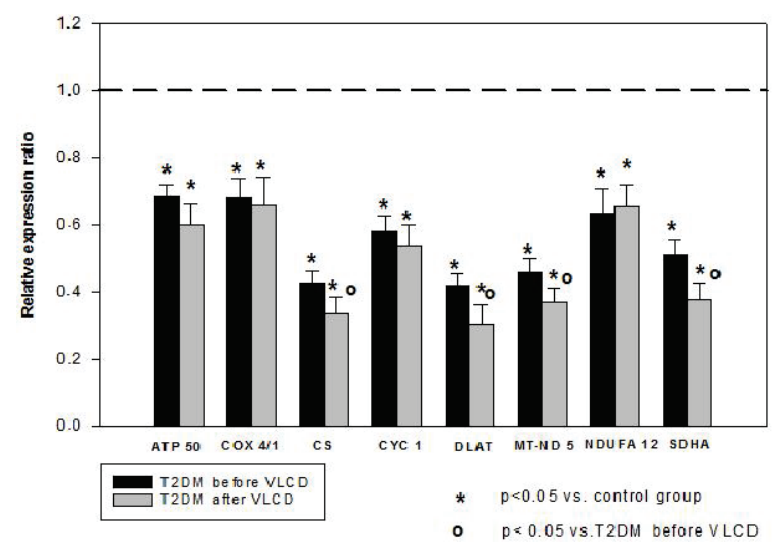

Fig. 1. mRNA expression of mitochondrial genes in subcutaneous adipose tissue (SCAT) of obese T2DM subjects before $(n=16$, black bar) and after $\operatorname{VLCD}(n=16$, grey bar). Values are means \pm SEM. The mean value of the relative gene expression of control group was taken as 1.0. T2DM - type 2 diabetes mellitus; VLCD - very low-calorie diet.

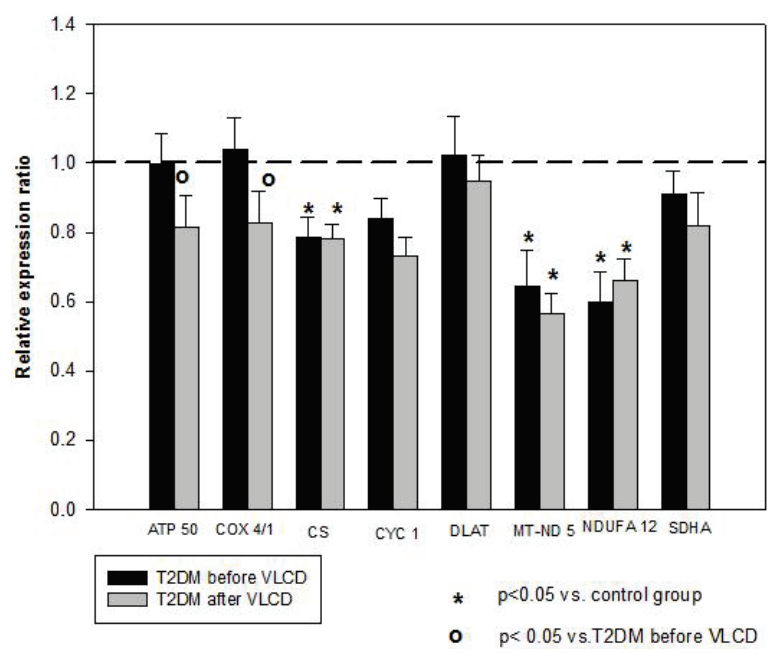

Fig. 2. mRNA expression of mitochondrial genes in peripheral monocytes (PM) of obese T2DM subjects before $(n=16$, black bar) and after VLCD $(n=16$, grey bar). Values are means \pm SEM. The mean value of the relative gene expression of control group was taken as 1.0. T2DM - type 2 diabetes mellitus; VLCD - very low-calorie diet.

\section{Discussion}

The most important finding of our study is that patients with obesity and T2DM had decreased mRNA expression of main enzymes involved in mitochondrial respiratory chain in SCAT and, to a lesser extent, also in PM relative to healthy lean subjects. The decreased expression of mitochondrial genes was even more pronounced in patients with T2DM relative to obese nondiabetic subjects. We have also demonstrated that patients with T2DM have partially impaired mitochondrial respiratory chain enzyme activity in peripheral blood elements. Short-term diet intervention

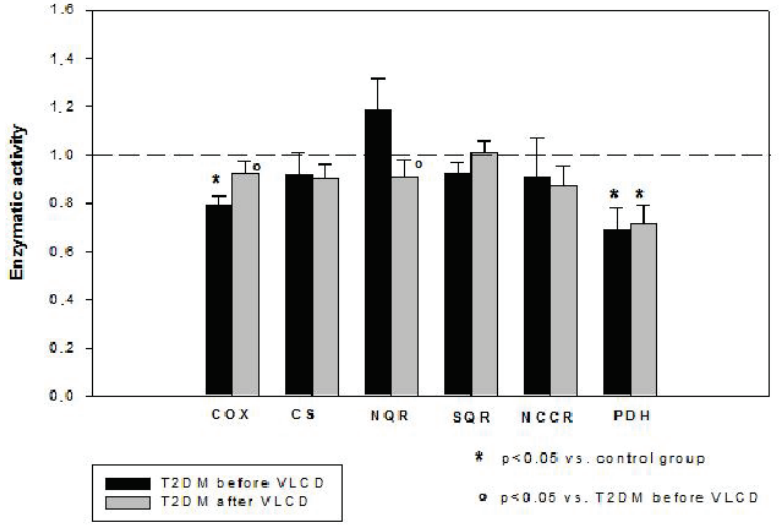

Fig. 3. Activity of respiratory chain enzymatic complexes in peripheral blood elements of obese T2DM subjects before $(n=16$, black bar) and after VLCD ( $n=16$, grey bar). Values are means \pm SEM. The mean value of the relative gene expression of control group was taken as 1.0. T2DM - type 2 diabetes mellitus; VLCD - very low-calorie diet.

had rather inconsistent effect on mitochondrial enzyme gene expression in SCAT and PM as well as their enzymatic activity, despite its overall positive influence on anthropometric, biochemical and hormonal parameters.

There is growing evidence that insulin resistance and the development of type 2 diabetes mellitus are closely related to mitochondrial function, total mitochondrial count and their abnormal morphology in skeletal muscle and adipose tissue, mainly its visceral compartment (Heinonen et al. 2015, Kim et al. 2008, Mitchell and Darley-Usmar 2012). High energy intake leads to electron overload of the mitochondrial respiratory chain complexes. Excess electrons are carried to oxygen that is subsequently converted to superoxide and other reactive oxygen species (ROS). ROS contribute to free fatty acid accumulation, insulin-sensitive tissue damage and possibly to the development of insulin resistance and $\beta$-cell failure (Meza-Miranda et al. 2014, Lowell and Shulman 2005). The main sites for ROS production in mitochondria are electron transport chain enzymatic complexes I and III (Kim et al. 2008). Here we show that the expression of almost all respiratory chain enzyme genes is markedly reduced already in subjects with simple obesity, which is in agreement with previously published works (Chattopadhyay et al. 2011). The presence of T2DM further enhances this dysfunction by decreasing the expression of the remaining genes (NDUFA 12 and COX 4/1). Interestingly, the 2 genes outside the respiratory chain - DLAT and CS - were reduced in a similar fashion indicating that preceding parts of the aerobic glycolytic pathway might be impaired 
as well. Moreover, as CS is considered a marker of mitochondrial mass (Civitarese et al. 2007, Merz et al. 2015), its decrease suggests that one of the main causes for the reduced respiratory chain enzyme mRNA expression might be the reduction in the amount of mitochondria. Collectively, these data further support the association between obesity and T2DM and impaired mitochondrial activity in subcutaneous white adipose tissue (Rieusset 2015, Brands et al. 2012, Dahlman et al. 2006, Gianotti et al. 2008).

Previous studies indicated the existence of complex interactions between circulating monocytes and adipose tissue in the development of low-grade systemic inflammation, insulin resistance and type 2 diabetes mellitus (Mraz et al. 2011, Harford et al. 2011). However, there is currently limited knowledge on the relationship between mitochondrial dysfunction in circulating peripheral monocytes and the development of metabolic diseases, mainly T2DM. Previous data suggest that the amount of mitochondrial DNA in PM of T2DM patients is reduced and may be related to disease pathogenesis and earlier disease onset (Lee et al. 1998, Wong et al. 2009). Here we show for the first time that simple obesity is associated with decreased mRNA expression of complex I enzymes (MT-ND5 and NDUFA 12) in PM. In addition, the presence of T2DM lowers the expression of CS suggesting also in PM a possible reduction of mitochondrial amount relative to healthy individuals as well as obese non-diabetic subjects (Civitarese et al. 2007). Nevertheless, as the expression of other respiratory chain enzymes was not affected in either group, it seems that compared with SCAT the mitochondria of PM are much less prone to disturbances associated with obesity and T2DM. This is in contrast with the situation in healthy individuals, where the expression of mitochondria-related genes was reported to be comparable between mononuclear blood cells and white visceral adipose tissue (Fabricius et al. 2010). Interestingly, when assessing the activity of respiratory chain enzymes in peripheral blood elements, we found, except of decreased activity of complex IV, an unexpected, albeit non-significant, increase in the activity of complex I (NQR). Whether this was a result of substrate surplus for the respiratory chain or, in contrast, a compensatory reaction to decreased activity of complex IV or PDH and whether it could be responsible for increased production of ROS remains questionable.

In our previous works, we have demonstrated beneficial effects of short-term calorie restriction and regular physical activity on the metabolic and proinflammatory profile of obese and diabetic patients (Mraz et al. 2011, Touskova et al. 2012, Kloučková et al. 2016, Trachta et al. 2014). In the present study, 3 weeks of VLCD had a rather inconsistent effect on mRNA expression of respiratory chain enzymes with no significant improvement in any of the studied genes. Conversely, despite markedly improved overall metabolic parameters, several genes had even reduced mRNA expression including CS, DLAT and MT-ND5 in SCAT and COX 4/1 and ATP 50 in PM. These findings are in contrast with recent data that indicate a positive effect of long-term calorie restriction and large weight loss after bariatric surgery on mitochondrial biogenesis in patients with obesity (Lopez-Lluch et al. 2006, Vijgen et al. 2013, Nijhawan et al. 2013, Jahansouz et al. 2015, Coen et al. 2015). Whether this lack of effect of weight loss on mRNA expression of respiratory chain enzymes might be attributable to the different type or a much shorter duration of the intervention or to the fact, that acute weight reduction is per se a stressful procedure associated e.g. with increased expression of proinflammatory cytokines in adipose tissue (Snel et al. 2011), remains to be further elucidated. However, the normalization of the increased activity of complex I and reduced activity of complex IV in peripheral blood elements after VLCD suggests that even short-term diet intervention can improve mitochondrial function regardless of its influence on the expression level.

The use of slightly different cell types (peripheral monocytes vs. blood platelets) to assess mRNA expression and activity of mitochondrial enzymes might to some extent limit the interpretation and extrapolation of our results, even though both PM and platelets are being routinely employed as a convenient source of mitochondria when evaluating their morphology and function (Zharikov and Siva 2013, Widlansky et al. 2010). As the activity of citrate synthase rather than its mRNA expression is primarily used to quantify mitochondrial mass, the decrease in CS mRNA expression might not completely translate into similar reduction of mitochondrial amount. Analogously, mRNA expression of mitochondrial genes might not fully reflect the actual enzymatic activity of respiratory chain complexes. The relatively lower number of subjects in each group also constitutes a potential limitation of our study. In summary, obesity and type 2 diabetes mellitus were in our study associated with impaired mRNA expression of mitochondrial enzyme genes in 
subcutaneous adipose tissue and in part also in peripheral blood elements. Three weeks of strict caloric restriction lead to overall improvement of anthropometric and metabolic parameters in obese diabetic patients along with amelioration of mitochondrial oxidative function in peripheral blood elements, while having an inconsistent and rather non-significant effect on mitochondrial gene mRNA expression in both SCAT and PM.

\section{Conflict of Interest}

There is no conflict of interest.

\section{Acknowledgements}

Supported by RVO VFN64165 and MH CZ - DRO (,Institute for Clinical and Experimental Medicine IKEM, IN 000023001").

\section{References}

ALBERTI KG, ZIMMET P: Global burden of disease--where does diabetes fit in? Nat Rev Endocrinol 9: 258-260, 2013.

BENJAMINI Y, HOCHBERG Y: Controlling the false discovery rate: a practical approach to multiple testing. $J$ R Statist Soc B 57: 289-300, 1995.

BOHM M, HONZIK T, SNAJPERKOVA A, KNOPOVA S, ZEMAN J, HANSIKOVA H: Activities of respiratory chain complexes in isolated platelets. Klin Biochem Metab 11: 97-101, 2003.

BRANDS M, VERHOVEN AJ, SERLIE MJ: Role of mitochondrial function in insulin resistance. Adv Exp Med Biol 942: $215-34,2012$.

CHATTOPADHYAY M, GUHATHAKURTA I, BEHERA P, RANJAN KR, KHANNA M, MUKHOPADHYAY S, CHAKRABARTI S: Mitochondrial bioenergetics is not impaired in non-obese subjects with type 2 diabetes mellitus. Metabolism 60: 1702-1710, 2011.

CIVITARESE AE, CARLING S, HEILBRONN LK, HULVER MH, UKROPCOVA B, DEUTSCH WA, SMITH SR, RAVUSSIN E: Calorie restriction increases muscle mitochondrial biogenesis in healthy humans. PLoS Med 4: e76, 2007.

COEN PM, MENSHIKOVA V, DISTEFANO G, ZHENG D, TANNER CJ, STANDLEY RA, HELBLING NL, DUBIS GS, RITOV VB, XIE H, ET AL.: Exercise and weight loss improve muscle mitochondrial respiration, lipid partitioning, and insulin sensitivity after gastric bypass surgery. Diabetes 64: 3737-3750, 2015.

CONSTANTIN-TEODOSIU D, CEDERBLAD G, HULTMAN E: A sensitive radioisotopic assay of pyruvate dehydrogenase complex in human muscle tissue. Anal Biochem 198: 347-351, 1991.

DAHLMAN I, FOSGREN M, SJORGEN A, NORDSTROM EA, KAAMAN M, NASLUND E, ATTERSAND A, ARNER P: Downregulation of electron transport chain genes in visceral adipose tissue in type 2 diabetes independent of obesity and possibly involving tumor necrosis factor- $\alpha$. Diabetes 55: 1792-1799, 2006.

DEL POZO CH, CALVO RM, VESPERIUAS-GARCIA G, GÓMEZ-AMBROSI J, FRÜHBECK G, RUBIOMA, OBREGON MJ: Expression profile in omental and subcutaneous adipose tissue from lean and obese subjects. Repression of lipolytic and lipogenic genes. Obes Surg 21: 633-643, 2011.

DOLEZALOVA R, LACINOVA Z, DOLINKOVA M, KLEBLOVA P, HALUZIKOVA D, HOUSA D, PAPEZOVA $\mathrm{H}$, HALUZIK M: Changes of endocrine function of adipose tissue in anorexia nervosa: comparison of circulating levels versus subcutaneous mRNA expression. J Clin Endocrinol 67: 674-678, 2007.

DUCHEN MR: Mitochondria in health and disease: perspectives on a new mitochondrial biology. Mol Aspects Med 25: 365-451, 2004.

FABRICIUS MH, WILMS LK, LARSEN J, PEDERSEN PL, ANTHONSEN S, KVETNY J: Measure of expression of mitochondrial related genes in human mononuclear blood cells, adipose white tissue and smooth muscle cells. Clin Chim Acta 41: 749-753, 2010.

FISCHER B, SCHÖTTL T, SCHEMPP CH, FROMME T, HAUNER H, KLINGENSPOR M, SKURK T: Inverse relationship between body mass index and mitochondrial oxidative phosphorylation capacity in human subcutaneous adipocytes. Am J Physiol Endocrinol Metab 309: E380-E387, 2015.

FRIEDEWALD WT, LEVY RI, FREDRICKSON DS: Estimation of the concentration of low-density lipoprotein cholesterol in plasma, without use of the preparative ultracentrifuge. Clin Chem 18: 499-502, 1972. 
FOX JEB, REYNOLDS CC, BOYLES JK: Studying the platelet cytoskeleton in Triton X-100 lysates. Methods Enzymol 215: 42-47, 1992.

GELLERICH FN, DESCHAUER M, CHEN Y, MULLER T, NEUDECKER S, ZIERZ S: Mitochondrial respiratory rates and activities of respiratory chain complexes correlate linearly with heteroplasmy of deleted mtDNA without threshold and independently of deletion size. Biochim Biophys Acta 1556: 41-52, 2002.

GIANOTTI TF, SOOKOIAN S, DIEUZEIDE G, GARCÍA SI, GEMMA C, GOZÁLEZ CD, PIROLA CJ: A decreased mitochondrial DNA content is related to insulin resistance in adolescents. Obesity 16: 1591-1595, 2008.

GRAMS J, GARVEY WT: Weight loss and the prevention and treatment of type 2 diabetes using lifestyle therapy, pharmacotherapy, and bariatric surgery: mechanisms of action. Curr Obes Rep 4: 287-302, 2015.

HARFORD KA, REYNOLDS CM, MCGILLICUDDY FC, ROCHE HM: Fats, inflammation and insulin resistance: insights to the role of macrophage and T-cell accumulation in adipose tissue. Proc Nutr Soc 70: 408-417, 2011.

HEINONEN S, BUZKOVA J, MUNIANDY M, KAKSONEN R, OLLIKAINEN M, ISMAIL K, HAKKARAINEN A, LUNDBOM J, LUNDBOM N, VUOLTEENAHO K, ET AL.: Impaired mitochondrial biogenesis in adipose tissue in acquired obesity. Diabetes 64: 3135-3145, 2015.

HOTAMISLIGLI GS: Inflammation and metabolic disorders. Nature 14: 860-867, 2006.

INDULEKHA K, ANJANA RM, SURENDAR J, MOHAN V: Association of visceral and subcutaneous fat with glucose intolerance, insulin resistance, adipocytokines and inflammatory markers in Asian Indians (CURES113). Clin Biochem 44: 281-287, 2011.

INTERNATIONAL DIABETES FEDERATION. IDF Diabetes Atlas. $6^{\text {th }}$ edn. Brussels: International Diabetes Federation, 2013. http://www.idf.org/diabetesatlas.

JAHANSOUZ C, SERROT FJ, FROHNERT BI, FONCEA RE, DORMAN RB, SLUSAREK B, LESLIE DB, BERNLOHR DA, IKRAMUDDIN S: Roux-en-Y bypass acutely decreases protein carbonylation and increases expression of mitochondrial biogenesis genes in subcutaneous adipose tissue. Obes Surg 25: 2376-2385, 2015.

KELLEY DE, HE J, MENSHIKOVA EV, RITOV VB: Dysfunction of mitochondria in human skeletal muscle in type 2 diabetes. Diabetes 51: 2944-2950, 2002.

KIM J, WEI Y, SOWERS JR: Role of mitochondrial dysfunction in insulin resistance. Circ Res 102: 401-414, 2008.

KLOUČKOVÁ J, LACINOVÁ Z, KAVÁLKOVÁ P, TRACHTA P, KASALICKÝ M, HALUZÍKOVÁ D, MRÁZ M, HALUZÍK M: Plasma concentrations and subcutaneous adipose tissue mRNA expression of clusterin in obesity and type 2 diabetes mellitus: the effect of short-term hyperinsulinemia, very-low-calorie diet and bariatric surgery. Physiol Res 65: 481-492, 2016.

KRAUNSOE R, BOUSHEL R, HANSE CN, SCHJERLING P, QVORTRUP K, STOCKEL M, MIKINES KJ, DELA F: Mitochondrial respiration in subcutaneous and visceral adipose tissue from patients with morbid obesity. J Physiol 588: 2023-2032, 2010.

LAAKSO M, KUUSISTO J: Insulin resistance and hyperglycemia in cardiovascular disease development. Nat Rev Endocrinol 10: 293-302, 2014.

LEE HK, SONG JH, SHIN CS, PARK DJ, PAR KS, LEE UK, KOH CS: Decreased mitochondrial DNA content in peripheral blood precedes the development of non-insulin-dependent diabetes mellitus. Diabetes Res Clin Pract 42: 161-167, 1998.

LÓPEZ-LLUCH G, HUNT N, JONES B, ZHU M, JAMIESON H, HILMER S, CASCAJO MV, ALLARD J, INGRAM DK, NAVAS P, DE CABO R: Calorie restriction induces mitochondrial biogenesis and bioenergetics efficiency. Proc Natl Acad Sci U S A 103: 1768-1773, 2006.

LOWELL BB, SHULMAN GI: Mitochondrial dysfunction and type 2 diabetes. Science 307: 384-387, 2005.

LOWRY OH, ROSEBROUGH NJ, FARR AL, RANDALL RJ: Protein measurement with the Folin phenol reagent. J Biol Chem 193: 265-275, 1951.

MATLOCH Z, KOTULÁK T, HALUZÍK M: The role of epicardial fat tissue in heart disease. Physiol Res 65: 23-32, 2016.

MERZ TM, PICHLER HEFTI J, HEFTI U, HUBER A, JAKOB SM, TAKALA J, DJAFARZADEH S: Changes in mitochondrial enzymatic activities of monocytes during prolonged hypobaric hypoxia and influence of antioxidants: A randomized controlled study. Redox Rep 20: 234-240, 2015. 
MEZA-MIRANDA ER, CAMARGO A, RANGEL-ZUNIGA OA, DELGADO-LISTA J, GARCIA-RIOS A, PEREZMARTINEZ P, TASSET-CUEVAS I, TUNEZ I, TINAHONES FJ, PEREZ-JIMENEZ F, LOPEZ-MIRANDA $\mathrm{J}$ : Postprandial oxidative stress is modulated by dietary fat in adipose tissue from elderly people. Age (Dordr) 36: 507-517, 2014.

MITCHELL T, DARLEY-USMAR V: Metabolic syndrome and mitochondrial dysfunction: insights from preclinical studies with a mitochondrially targeted antioxidant. Free Radic Biol Med 52: 838-840, 2012.

MOOTHA VK, LINDGREN CM, ERIKSSON KF, SUBRAMANIAN A, SIHAG S, LEHAR J, PUIGSERVER P, CARLSSON E, RIDDERSTRALE M, LAURILA E, ET AL.: PGC-1 $\alpha$-responsive genes involved in oxidative phosphorylation are coordinately downregulated in human diabetes. Nat Genet 34: 267-273, 2003.

MORINO K, PETERSEN KF, DUFOUR S, BEFROY D, FRATTINI J, SHATZKES N, NESCHEN S, WHITE MF, BILZ S, SONO S, PYPAERT M, SHULMAN GI: Reduced mitochondrial density and increased IRS-1 serine phosphorylation in muscle of insulin-resistant offspring of type 2 diabetic parents. $J$ Clin Invest 115 : 3587-3593, 2005.

MRAZ M, LACINOVA Z, DRAPALOVA J, HALUZIKOVA D, HORINEK A, MATOULEK M, TRACHTA P, KAVALKOVA P, SVACINA S, HALUZIK M: The effect of very-low-calorie diet on mRNA expression of inflammation-related genes in subcutaneous adipose tissue and peripheral monocytes of obese patients with type 2 diabetes mellitus. J Clin Endocrinol Metab 96: 606-613, 2011.

MUSTELIN L, PIETILÄINEN KH, RISSANEN A, SOVIJÄRVI AR, PIIRILÄ P, NAUKKARINEN J, PELTONEN L, KAPRIO J, YKI-JÄRVINEN H: Acquired obesity and poor physical fitness impair expression of genes of mitochondrial oxidative phosphorylation in monozygotic twins discordant for obesity. Am J Physiol Endocrinol Metab 295: E148-E154, 2008.

NIJHAWAN S, RICHARDS W, O'HEA MF, AUDIA JP, ALVAREZ DF: Bariatric surgery rapidly improves mitochondrial respiration in morbidly obese patients. Surg Endosc 27: 4569-4573, 2013.

PANENI F, CONSTANTINO S, CONSTANTINO F: Insulin resistance, diabetes, and cardiovascular risk. Curr Atheroscler Rep 16: 419, 2014.

PETERSEN KF, DUFOUR S, BEFROY D, GARCIA R, SHULMAN GI: Impaired mitochondrial activity in the insulin-resistant offspring of patients with type 2 diabetes. $N$ Engl J Med 350: 664-671, 2004.

RASOULI N, KERN PA: Adipocytokines and the metabolic complications of obesity. J Clin Endocrinol Metab 93: 64-73, 2008.

RIEUSSET J: Contribution of mitochondria and endoplasmic reticulum dysfunction in insulin resistance: Distinct or interrelated roles? Diabetes Metab 41: 358-368, 2015.

RITZ P, BERRUT G: Mitochondrial function, energy expenditure, aging and insulin resistance. Diabetes Metab 31: 5S67-5S73, 2005.

SCARPELLINI E, TACK J: Obesity and metabolic syndrome: an inflammatory condition. Dig Dis 30: 148-153, 2012.

SIVITZ WI, YOREK MA: Mitochondrial dysfunction in diabetes: from molecular mechanism to functional significance and therapeutic opportunities. Antioxid Redox Signal 12: 537-577, 2010.

SNEL M, VAN DIEPEN JA, STIJNEN T, PIJL H, ROMIJIN JA, MEINDERS AE, VOSHOL P, JAZET IM: Immediate and long-term effects if addition of exercise to a 16-week very low calorie diet on low-grade inflammation in obese, insulin-dependent type 2 diabetic patients. Food Chem Toxicol 49: 3104-3111, 2011.

SORONEN J, LAURILA PP, NAUKKARINEN J, SURAKKA I, RIPATTI S, JAUHIAINEN M, OLKKONEN VM, YKI-JÄRVINEN H: Adipose tissue gene expression analysis reveals changes in inflammatory, mitochondrial respiratory and lipid metabolic pathways in obese insulin-resistant subjects. BMC Med Genomics 5: 9, 2012.

SRERE PA: Citric acid cycle. Methods Enzymol 13: 3-11, 1969.

STUMVOLL M, GERICH J: Clinical features of insulin resistance and beta cell dysfunction and the relationship to type 2 diabetes. Clin Lab Med 21: 31-51, 2001.

SUGANAMI T, NISHIDA J, OGAWA Y: A paracrine loop between adipocytes and macrophages aggravates inflammatory changes: role of free fatty acids and tumor necrosis factor alpha. Arterioscler Thromb Vasc Biol 25: 2062-2068, 2005. 
TOUSKOVA V, TRACHTA P, KAVALKOVA P, DRAPALOVA J, HALUZIKOVA D, MRAZ M, LACINOVA Z, MAREK J, HALUZIK M: Serum concentrations and tissue expression of components of insulin-like growth factor-axis in females with type 2 diabetes mellitus and obesity: The influence of very-low-calorie diet. $\mathrm{Mol}$ Cell Endocrinol 361: 172-178, 2012.

TRACHTA P, DRÁPALOVÁ J, KAVÁLKOVÁ P, TOUŠKOVÁ V, CINKAJZLOVÁ A, LACINOVÁ Z, MATOULEK M, ZELINKA T, WIDIMSKÝ J JR, MRÁZ M, HALUZÍK M: Three months of regular aerobic exercise in patients with obesity improve systemic subclinical inflammation without major influence on blood pressure and endocrine production of subcutaneous fat. Physiol Res 63 (Suppl 2): S299-S308, 2014.

VIJGEN GH, BOUVY ND, HOEKS J, WIJERS S, SCHRAUWEN P, VAN MARKEN LICHTENBELT WD: Impaired skeletal muscle mitochondrial function in morbidly obese patients is normalized one year after bariatric surgery. Surg Obes Relat Dis 9: 936-941, 2013.

VIGNERI P, FRASCA F, SCIACCA L, PANDINI G, VIGNERI R: Diabetes and cancer. Endocr Relat Cancer 16: 1103-1123, 2009.

WAJCHENBERG BL: Subcutaneous and visceral adipose tissue: their relation to the metabolic syndrome. Endocr Rev 21: 697-738, 2000.

WIDLANSKY ME, WANG J, SHENOUDA SM, HAGEN TM, SMITH AR, KIZHAKEKUTTU TJ, KLUGE MA, WEIHRAUCH D, GUTTERMAN D, VITA JA: Altered mitochondrial membrane potential, mass, and morphology in the mononuclear cells of humans with type 2 diabetes. Transl Res 156: 12-25, 2010.

WONG J, MCLENNAN SV, MOLYNEAUX L, MIN D, TWIGG SM, YUE DK: Mitochondrial DNA content in peripheral blood monocytes: relationship with age of diabetes onset and diabetic complications. Diabetologia 52: 1953-1961, 2009.

ZHARIKOV S, SHIVA S: Platelet mitochondrial function: from regulation of thrombosis to biomarker of disease. Biochem Soc Trans 41: 118-123, 2013. 